\title{
LONG-TIME DRIFT INDUCED CHANGES IN ELECTRICAL CHARACTERISTICS OF GRAPHENE-METAL CONTACTS
}

\author{
A. Sakavičius, V. Agafonov, V. Bukauskas, T. Daugalas, M. Kamarauskas, A. Lukša, \\ V. Nargelienè, G. Niaura, M. Treideris, and A. Šetkus \\ State Research Institute Center for Physical Sciences and Technology, Savanoriu 231, 02300 Vilnius, Lithuania \\ Email: andrius.sakavicius@ftmc.lt
}

Received 3 May 2020; revised 3 July 2020; accepted 1 September 2020

\begin{abstract}
Chemical vapour deposition (CVD) graphene is commonly recognized as promising 2D material for development of electronic devices. However, the long-term drift of electrical parameters still requires deeper understanding before the technological means can be selected for an individual type of the devices. In this work, the changes in the electrical resistance were investigated over long time in the planar samples based on the CVD graphene with Au and $\mathrm{Ni}$ contacts. The samples were arranged as arrays of the resistors on a silicon substrate covered with a $250 \mathrm{~nm}$ layer of thermally grown silicon dioxide. The annealing in pure argon gas flow at $573 \mathrm{~K}$ was used to return the electrical properties of samples to the initial state. The effects of drift and annealing were compared for the three parts of structures, namely the electrical contact, the graphene sheet and the edge of the metal film with a hanging graphene sheet. For these parts, the resistance changes were related to the strain and doping of supported and hanged parts of the graphene sheet. Raman spectroscopy and Kelvin force probe microscopy were used to characterize charge doping, strain and work function in the graphene. The drift was explained in terms of the most prominent changes in the doping, strain and work function detected within the edge zone of the contact. It was proved that the annealing significantly changed the $p$-type doping and work function in the graphene layer in this edge zone. The properties were almost independent of test conditions in the $\mathrm{SiO}_{2}$ supported graphene. The changes in the contact parameters produced by drift mechanisms were proved being reversible under proper annealing conditions.
\end{abstract}

Keywords: long-time drift, graphene, graphene-metal contacts, Raman spectroscopy, scanning probe microscopy, strain and doping in CVD graphene

PACS: $72.80 . \mathrm{Vp}, 68.65 . \mathrm{Pq}$

\section{Introduction}

Due to its exclusive electrical, optical and mechanical properties the chemical vapour deposition (CVD) graphene is a very attractive material for development of photonic and gas sensing devices. This carbon monolayer material has no band gap; however, graphene attracts scientific interest for its high electron mobility, optical properties, mechanical strength and flexibility, and highly promising modification ways in combination with other $2 \mathrm{D}$ materials.

In order to improve the electrical properties of graphene-based devices, various methods were developed for the contact formation and optimiza- tion. Typically, the metal electrodes to graphene sheets are formed in two ways producing diverse constructions, namely as edge and vertical arrangement structures. Both of the arrangements can lead to highly promising applications; however, the vertical arrangement of the structures appears to be a more attractive choice for a layer by layer approach in the device fabrication. The vertical structure can be obtained as top-contacting and bottom-contacting versions. The bottom-contacting approach has advantages in comparison with the top-contacting, because quite complicated technological steps can be omitted. This simplification reduces the possibility to create additional defects in the graphene sheet. 
Usually graphene in bottom-contacting devices is used for development of photodetectors, spintronic and electronic devices, modulators, optical systems and humidity sensors [1-5]. In this work, the bottom-contacting way was employed for fabrication of the circular transmission line method (CTLM) samples which were used to investigate the longterm stability.

Graphene-based devices have some breakthrough limiting factors including a high contact resistance and a drift in the electrical characteristics over long time of functioning. The long-term drift of electrical parameters was typically obtained in the graphene based electronic devices without a proper insulation after the fabrication [6-5]. The changes were known being more significant for the graphene structures exposed to gases such as $\mathrm{NH}_{3}, \mathrm{CO}, \mathrm{H}_{2} \mathrm{O}$ and $\mathrm{NO}_{2}$ [6]. There were reported attempts in literature [9-11] focused on understanding of the long-time stability problems. In [9], the changes in properties over time were described for the graphene sheets grown on the $\mathrm{Cu}$ substrate. An influence of the atmosphere was explained for the graphene sheets in Refs. [10, 11]. The detected changes were explained by the changes in the doping and strain that resulted in the drift of electrical parameters in the graphene sheets. More detailed results about the drift in the contact and sheet resistances of the graphene sample were reported in Ref. [12].

However, understanding of the mechanisms that control the changes in the parameters of graphene devices exposed to the atmosphere does not reveal the complete picture of the problems related to the long-term drift of device parameters. In addition, there is no reliable information about whether reversible or not are the changes in the device parameters after a long-time exposure to the atmosphere. A detailed analysis of the combined results of electrical and Raman measurements can provide much deeper understanding about possibilities to restore the initial state in the graphene based devices after the long-term drift. Therefore, such an approach is highly demanded to improve the development and performance of graphene devices.

In this work, we presented the results of investigations on the drift of CVD graphene based bottom-contacting resistors. The effects of drift and annealing were studied in the sample structures that included the parts of the same graphene monolayer in diverse regions of the device, namely on the $\mathrm{SiO}_{2}$ substrate, on the metal electrodes and at the edges of metal film contacts. The results of electrical, Raman and scanning probe microscopy (SPM) measurements were used to compare the changes in the characteristics of graphene samples after the long-time drift and annealing. Our results proved that the largest changes in the doping occurred in the graphene at the edges of metal film contacts and on the metal electrodes. The drift and restoration in tensile strain was observed in the graphene on the Au electrodes. In addition, the drift and restoration in compressive strain was observed in the graphene on the $\mathrm{Ni}$ film. Based on the SPM experiments, it was proved that the annealing had changed the work function in the graphene in diverse regions of the samples.

\section{Materials and preparation}

A simplified version of the model devices was fabricated and investigated in this work. Samples were arranged as an array of resistors, each with two metallic electrodes and a graphene sheet as a resistance layer. The resistors in the array were shaped as concentric circular elements, each including a large outside electrode and a disk-like inside electrode. The diameter of the inside electrode was $100 \mu \mathrm{m}$. The gap between the outside and the inside electrodes was individual for each resistor and ranged from 5 to $30 \mu \mathrm{m}$. These resistors were included in the samples in a way acceptable to use the CTLM approach for calculations of the contact and the layer resistances that quantitatively separated the integral parts of the total resistance of resistors. The arrangement of the samples is illustrated by a scheme in Fig. 1(a). Metallic films of Au and Ni were used for the electrodes. The films were deposited by a magnetron sputtering machine (AMOD, Angstrom Engineering) from pure metal targets in $5 \mathrm{~N}$ Ar atmosphere. The thickness of $\mathrm{Au}$ and Ni films was 160 and $80 \mathrm{~nm}$, respectively. The CTLM samples were patterned by photolithography. The lift-off method was used for shaping of the electrodes. A cross-section of the contact area is illustrated in Fig. 1. (b).

The monolayer graphene was obtained from Graphenea (Spain). The monolayer was mechanically transferred from the growth substrates ( $\mathrm{Cu}$ foil) on the silicon plate with CTLM electrodes. We have used the technique proposed by Kang et al. [13. The conditions of the wet chemical processes and 

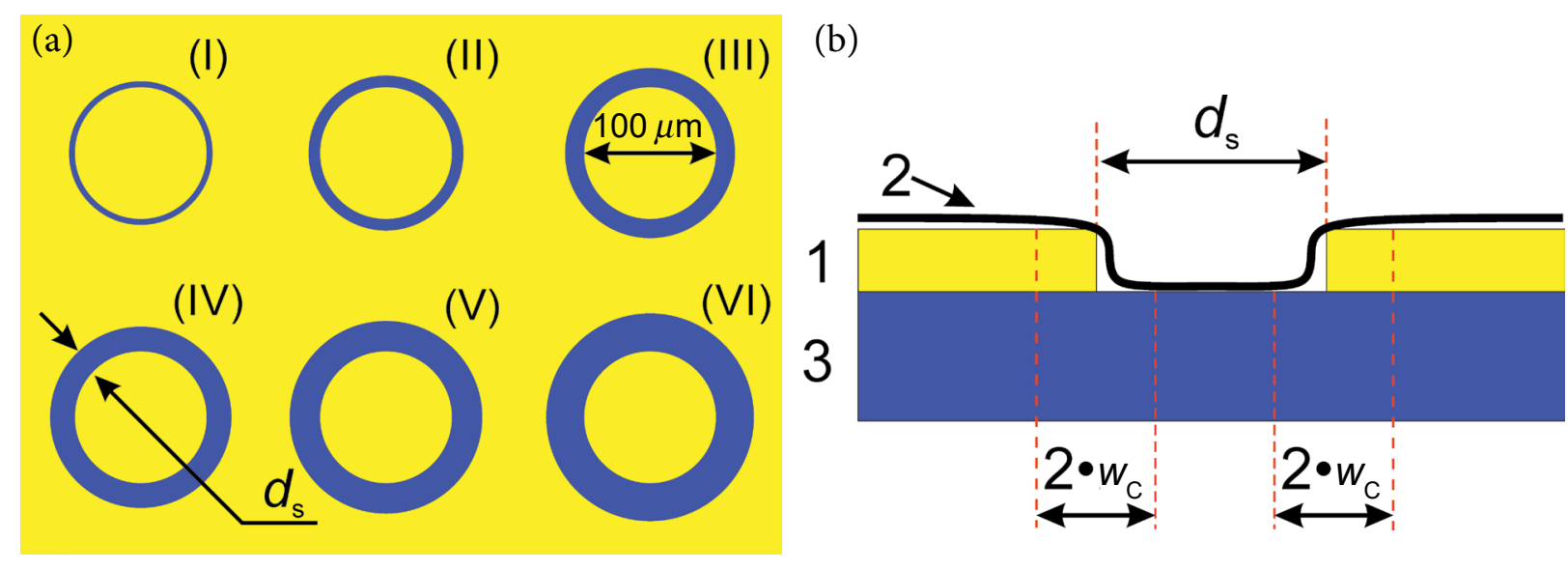

Fig. 1. (a) Layout of the samples with the array of CTLM resistors. Diameter of the inner disk-shape contact is $100 \mu \mathrm{m}$. Distance $d_{\mathrm{s}}$ between the inner and the outer electrodes: $5 \mu \mathrm{m}$ (I), $10 \mu \mathrm{m}$ (II), $15 \mu \mathrm{m}$ (III), $20 \mu \mathrm{m}$ (IV), $25 \mu \mathrm{m}$ (V) and $30 \mu \mathrm{m}$ (VI). (b) Drawing of the cross-section of a resistor with a thin metal film electrode (1), graphene sheet (2) and solid substrate (3). $w_{\mathrm{C}}$ is the distance of the contact edge zone.

poly(methyl methacrylate) (PMMA) transfer on substrate were adapted to the fabrication process of the samples in our previous work [14].

\section{Characterizations and processing}

The graphene based samples were annealed in a rapid thermal annealing furnace (Unitemp RTP $100 \mathrm{HW}$, UniTemp $\mathrm{GmbH}$ ). The rate of pure Ar gas flow was $2 \mathrm{l} / \mathrm{min}$. The rate of the temperature increase was $10 \mathrm{deg} / \mathrm{s}$. The samples were annealed at $573 \mathrm{~K}$ constant temperature during diverse periods from 1 to $124 \mathrm{~min}$.

The surfaces of CTLM samples were characterized by Raman spectroscopy. The Raman maps were obtained from the Raman spectra measured at room temperature in the laboratory atmosphere. The Raman spectra were obtained by an inVia spectrometer (Renishaw, UK) with a CCD camera that was thermo-electrically cooled down to $-70^{\circ} \mathrm{C}$. The excitation was produced by $532 \mathrm{~nm}$ wavelength radiation of a solid state laser and the beam was focused into the spot with a diameter of about $1 \mu \mathrm{m}$ on the sample surface. A 50×/0.75NA objective was used during the measurements. The excitation power at the sample surface did not exceed $5 \mathrm{~mW}$. The Raman scattering wavenumber axis was calibrated by the silicon peak at $520.7 \mathrm{~cm}^{-1}$. For the Raman mapping measurements a $1 \mu \mathrm{m}$ scan step was used while the $60 \times 60 \mu \mathrm{m}^{2}$ area of CTLM contacts was scanned. The parameters of bands in the Raman spectra were calculated by fitting the experimental spectra with Lorentzian shape components.
Measurements of the voltage-current $(I-V)$ characteristics were performed by a 4200-SCS parameter analyzer (Keithley Instruments, Inc.) in a Summit probe station 11000/12000 (Cascade Microtech, Inc.). The electrical resistance $R_{\mathrm{d}}$ of the CTLM samples was obtained from the $I-V$ characteristics. All electrical measurements were made under the ambient conditions.

The surface morphology and the contact potential difference (CPD) were obtained for the CTLM samples by atomic force microscopy (AFM) and Kelvin probe force microscopy (KPFM), respectively. Measurements were performed by a SPM D3100/nanoscope IVa (Veeco) instrument under the ambient conditions. The AFM topography images were obtained in the tapping mode. The CPD was measured by KPFM with a constant probe lift of $20 \mathrm{~nm}$ above the surface. The controlled amplitude modulation was used in these measurements. The frequency of the modulation was equal to the eigen-frequency of the cantilever. The obtained surface potential was calibrated on a highly oriented pyrolytic graphite (HOPG) substrate and the work function was calculated. The CTLM samples were scanned over the square area with dimensions of about $60 \times 60 \mu \mathrm{m}^{2}$.

\section{Electric measurements}

It was demonstrated in our previous work [14] that graphene based resistors must be annealed after the formation of electronic devices. The results demonstrating changes in the total resistance, contact 
resistance and sheet resistance over a long period of staying under the ambient conditions were obtained for the CTLM samples in this work. The electrical characteristics were measured without a noticeable influence on the parameters of the resistors during a long period of staying under the ambient conditions. The long period of staying under the ambient conditions is defined as drift $t_{\text {drift }}$ time in our experiment. Based on the experiments, the total $R_{\mathrm{d}}$, contact $R_{\mathrm{C}}$ and graphene sheet $R_{\mathrm{sh}}$ resistances were obtained for the samples with Au and Ni contacts. An attempt to restore the initial magnitudes of the parameters was quantitatively described by a dependence of the resistances on the annealing time at $T_{\text {an }}=573 \mathrm{~K}$ in pure Ar atmosphere. The experimental results were summarized for the CTLM samples with the Au and $\mathrm{Ni}$ electrodes in Fig. 2. In the graphical representation, it was shown how the resistances drifted away and returned back with time.

The results of the long-time tests demonstrated that $R_{\mathrm{d}}$ decreased over time. $R_{\mathrm{d}}$ typically decreased by a factor of two over a single cycle of the drift away experiment. The change of resistance $R_{\mathrm{d}}$ was expressed as a relative parameter $R_{\mathrm{d}}(t) / R_{\mathrm{d}}\left(t_{0}\right)$. The results of $R_{\mathrm{d}}$ over the drift were normalized to the initial value $R_{\mathrm{d}}\left(t_{0}\right)$. It is assumed that the resistance is constant until the beginning of resistance drift. The resistance $R_{\mathrm{d}}(t)$ measured during the annealing time was normalized with respect to the resistance $R_{\mathrm{d}}\left(t_{0}\right)$ that was obtained after the final annealing step when the annealing time is equal to $124 \mathrm{~min}$. The total resistance $R_{\mathrm{d}}$ of the samples with $\mathrm{Au}$ contacts decreased from $R_{\mathrm{d}}(t) / R_{\mathrm{d}}\left(t_{0}\right)=1$ to 0.6

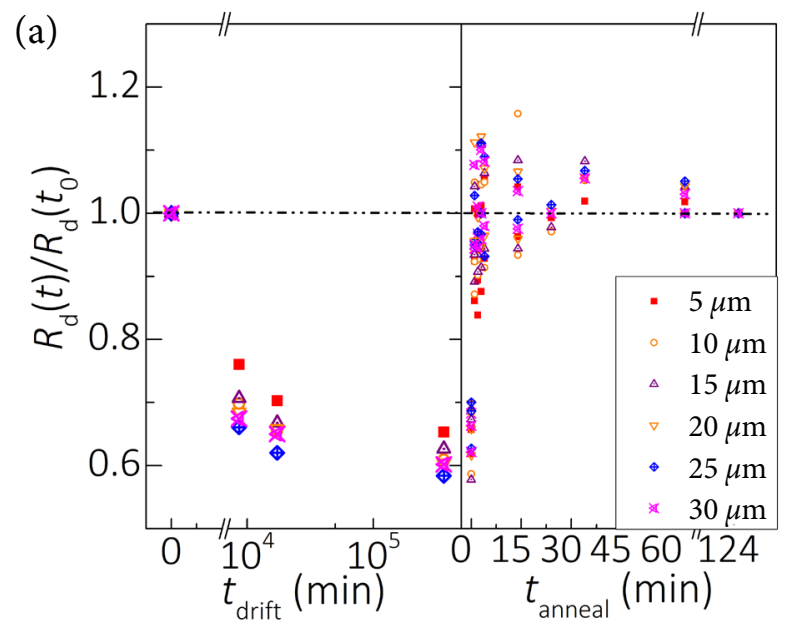

whereas, for the samples with Ni contacts, the $R_{\mathrm{d}}(t) /$ $R_{\mathrm{d}}\left(t_{0}\right)$ ratio decreased from 1 to 0.65 .

The annealing at $573 \mathrm{~K}$ was acceptable to restore the electrical parameters of the CTLM samples. The experimental results confirmed an increase in the total sample resistance $R_{\mathrm{d}}$ during the annealing. The relative total resistance for the Au contacts (Fig. 2(a)) and Ni contacts (Fig.2(b)) was restored to its initial magnitudes. Both the $\mathrm{Au}$ and $\mathrm{Ni}$ samples demonstrated steep growth in the total resistance after the contacts were annealed for a few minutes. The total resistance of the Au samples reached the initial value $R_{\mathrm{d}}(t) / R_{\mathrm{d}}\left(t_{0}\right)=1$ after the 3 min annealing. When the annealing time was increased, the resistance of the Au contacts remained almost unchanged. In contrast to the Au contacts, $R_{\mathrm{d}}$ of the Ni contacts rapidly increased up to about 1.4 and decreased during the short annealing for about $4 \mathrm{~min}$. When the annealing duration was above $4 \mathrm{~min}$, the total resistance began to reduce slowly and approached the initial magnitude about $R_{\mathrm{d}}(t) / R_{\mathrm{d}}\left(t_{0}\right)=1$.

Figure $3(a, b)$ shows relative changes in the contact resistance of the Au and Ni CTLM samples, respectively. The contact resistances of both the $\mathrm{Au}$ and $\mathrm{Ni}$ samples decreased over the entire period of the drift tests. Individual symbols in Fig. 3 represented the results that were obtained for an individual sample with a similar CTLM array. Compared to the initial magnitudes, the decrease in the $\mathrm{Au}$ and $\mathrm{Ni}$ contact resistances was very similar in both types of the samples. The contact resistance of each of the samples reached the value $R_{\mathrm{C}}(t) / R_{\mathrm{C}}\left(t_{0}\right)=0.7$. The contact resistance

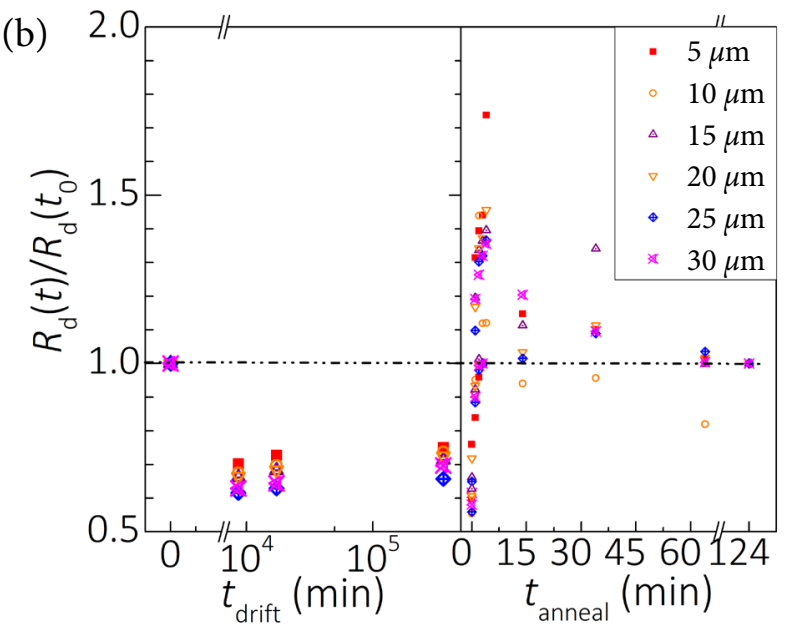

Fig. 2. Resistance of different elements of the CTLM array. Relative resistance dependence on the drift time $\left(t_{\text {drift }}\right)$ and annealing time $\left(t_{\text {anneal }}\right)$ of $\mathrm{Au}(\mathrm{a})$ and $\mathrm{Ni}(\mathrm{b})$ contacts. 

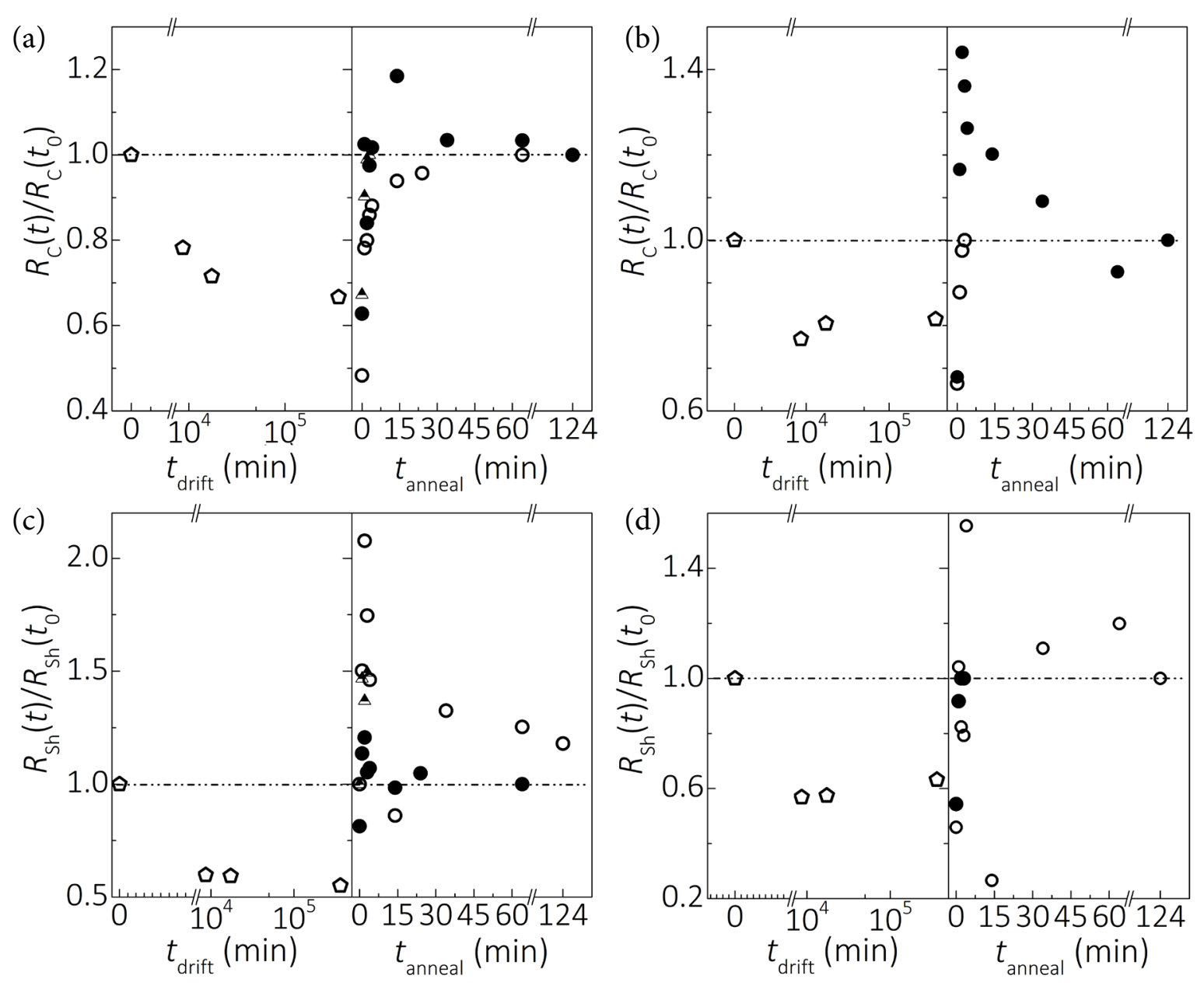

Fig. 3. Relative changes of the resistances with the experiment time $t_{\text {drift }}$ and the annealing period $t_{\text {anneal }}$ in long-term tests. Contact resistances $R_{\mathrm{C}}$ for $\mathrm{Au}(\mathrm{a})$ and $\mathrm{Ni}(\mathrm{b})$ and the graphene sheet resistances $R_{\mathrm{sh}}$ for the CTLM samples with $\mathrm{Au}(\mathrm{c})$ and $\mathrm{Ni}(\mathrm{d})$. Reference resistances $R_{\mathrm{X}}\left(t_{0}\right)$ were equal to the initial resistances after the fabrication.

has rapidly increased during annealing. $R_{\mathrm{C}}$ of the $\mathrm{Au}$ CTLM samples reached the maximum quantitative value in $15 \mathrm{~min}$ and after that $R_{\mathrm{C}}(t) /$ $R_{\mathrm{C}}\left(t_{0}\right)$ was equal to 1 . When the annealing time was above $15 \mathrm{~min}$, the relative contact resistance remained unchanged. $R_{\mathrm{C}}$ of the Ni CTLM samples approached the maximum relative value in a few minutes of the annealing. The maximum resistance was higher than the initial magnitude. $R_{\mathrm{C}}$ reached the value equal to $R_{\mathrm{C}}(t) / R_{\mathrm{C}}\left(t_{0}\right)=1.45$. $R_{\mathrm{C}}$ of the $\mathrm{Ni}$ contacts reduced after the following annealing and was approaching a relative value of 1 . Compared with $R_{\mathrm{C}}$ of the Au contacts, the contact resistance of the Ni samples demonstrated a faster restoration of $R_{\mathrm{C}}$ due to annealing. Moreover, the complete restoration of $R_{\mathrm{C}}$ was obtained over the annealing procedure for both the $\mathrm{Au}$ and Ni CTLM samples.

The dependence of relative sheet resistance on the drift and annealing time for the $\mathrm{Au}$ and $\mathrm{Ni}$ samples is demonstrated in Figs. 3( $(c, d)$. Different symbols represented the results that were obtained for the individual CTLM array on similar samples. As a result of the drift, the relative sheet resistance decreased from $R_{\mathrm{Sh}}(t) / R_{\mathrm{Sh}}\left(t_{0}\right)=1$ to $R_{\mathrm{Sh}}(t) / R_{\mathrm{Sh}}\left(t_{0}\right)=0.55$ for the Au CTLM samples. $R_{\mathrm{Sh}}$ of the Au samples was increased by the annealing. $R_{\mathrm{Sh}}$ reached the maximum relative value equal to 2.1 in $2 \mathrm{~min}$ of the annealing. When the annealing duration was above $2 \mathrm{~min}$, the sheet resistance decreased within the annealing time $t_{\text {annealing }}$. Finally, $R_{\mathrm{Sh}}$ of the Au sample reached the initial magnitude of sheet resistance after the whole annealing period. The relative sheet resistance of the Ni CTLM samples decreased from $R_{\mathrm{Sh}}(t) / R_{\mathrm{Sh}}\left(t_{0}\right)=1$ to $R_{\mathrm{Sh}}(t) /$ $R_{\mathrm{Sh}}\left(t_{0}\right)=0.57$ as a result of the drift. $R_{\mathrm{Sh}}$ of the $\mathrm{Ni}$ samples increased during the annealing and $R_{\mathrm{Sh}}$ was restored to the initial magnitude after the annealing. 


\section{Raman measurements}

Raman spectra were obtained for a series of the points on the CTLM samples over large areas of the sample surfaces. Graphene specific features in the Raman spectra were used to build up Raman maps for the tested samples. In all the maps, the bands commonly known as $\mathrm{G}$ and $2 \mathrm{D}$ modes in the Raman spectra were used to characterize the graphene monolayer. Typical Raman spectra of graphene on the $\mathrm{SiO}_{2}$ substrate, the edge zone of the contact and metal surfaces were shown in Fig. 4(a). The method to distinguish the edge zone of contacts was introduced in our previous work [15]. It was proved that long-distance distortions can be detected in the graphene monolayers at the edges of thin film contacts. These distortions were obviously higher than that produced by technological processes in the supported graphene on the flat zones including metal contact surfaces and the $\mathrm{SiO}_{2}$ substrate. In this work, we studied the changes in the distortion of graphene in various areas of our samples over the long-time tests. Based on that, it was possible to separate the mechanical strain from the charge doping in the graphene layers. As in the previous work [15], here we also used the method proposed by Lee et al. [16]. Dependences between the parameters of $2 \mathrm{D}$ and $\mathrm{G}$ modes of the graphene in different parts of the CTLM samples are presented in Fig. 4(b). A steep solid (wine online) line indicates the degree of strain $\varepsilon$ (\%) which represents the tensile strain for $\varepsilon(\%)>0$ and the compressive strain for $\varepsilon(\%)<0$. A more sloping solid (olive online) line represents the degree of doping $p\left(10^{13} \mathrm{~cm}^{-2}\right)$ in the graphene layer.

Changes in the strain $\varepsilon(\%)$ and charge doping $p\left(10^{13} \mathrm{~cm}^{-2}\right)$ in the $\mathrm{Au}$ and $\mathrm{Ni}$ graphene samples were observed during the resistance drift and annealing. Raman data was acquired from the scans of large surface areas therefore non-homogeneity in the graphene monolayer, especially in the graphene on metal films, could result in large error bars. Figure $5(a, b)$ shows the dependence of charge doping on the drift and annealing in the graphene on the edge zone of the contact for the CTLM samples. Different shapes of symbols represented the results that were obtained on the individual CTLM array on similar samples. The decrease of charge doping was observed over the drift period. The $p$-type doping of the Au sample decreased from $0.55 \times 10^{13}$ to $0.25 \times 10^{13} \mathrm{~cm}^{-2}$ during the resistance drift. The $p$ type doping was restored after the annealing. It increased from $0.25 \times 10^{13}$ to $0.8 \times 10^{13} \mathrm{~cm}^{-2}$. The degree of charge doping $p=1.05 \times 10^{13} \mathrm{~cm}^{-2}$ was obtained before the resistance drift in the Ni CTLM samples. The decrease of $p$-type doping was observed during the resistance drift. In terms of the resistance drift, the decrease of charge doping was measured and it was equal to about $0.6 \times 10^{13} \mathrm{~cm}^{-2}$. The charge density varied from $0.6 \times 10^{13}$ to $0.95 \times 10^{13} \mathrm{~cm}^{-2}$ in the $\mathrm{Ni}$ CTLM samples over the annealing. It was found that the annealing procedure restored the $p$-type doping
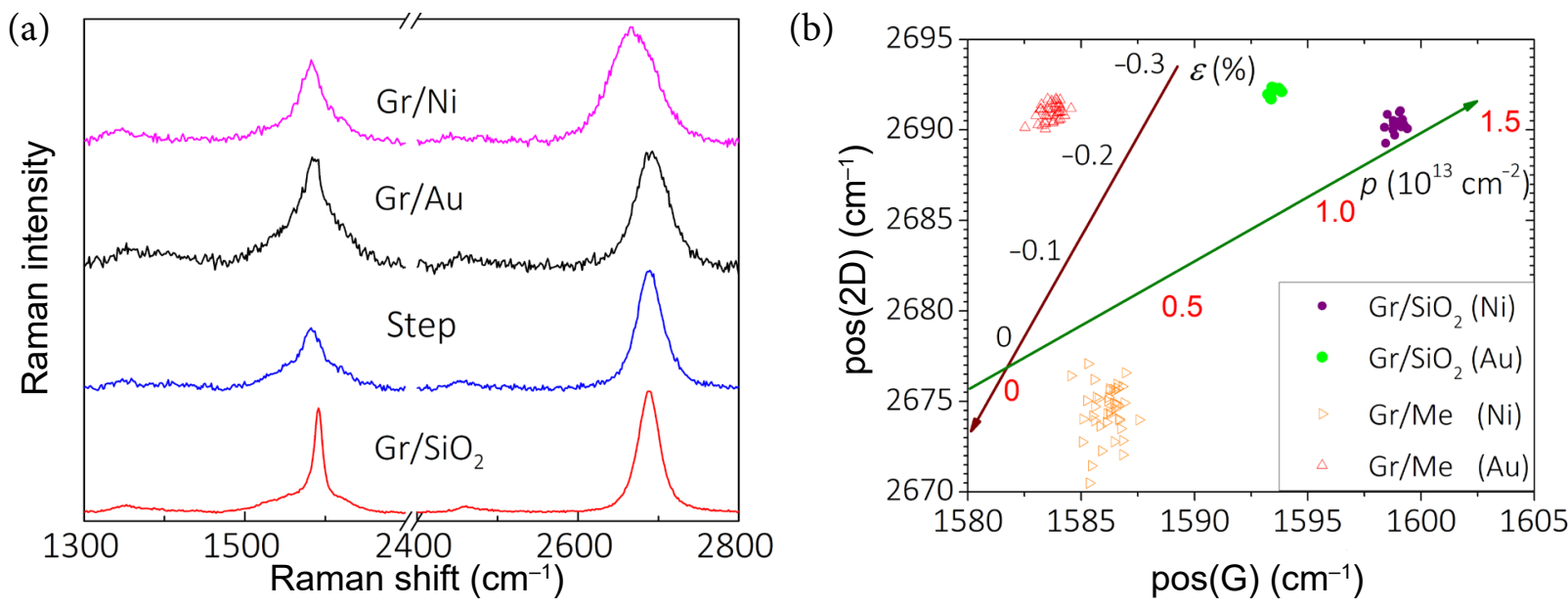

Fig. 4. (a) Raman spectra for graphene on $\mathrm{SiO}_{2}$ (red online), the edge zone of contact (blue online), $\mathrm{Au}$ (black) and $\mathrm{Ni}$ (purple online) substrates and (b) the dependence between the positions of 2D and G modes of graphene on $\mathrm{Au}$ (red (online) triangles) and $\mathrm{Ni}$ (orange (online) triangles) metal films and on $\mathrm{SiO}_{2}$ in the samples with $\mathrm{Au}$ (green (online) closed circles) and $\mathrm{Ni}$ (purple (online) closed circles) contacts. Green and purple (online) lines were adapted from [16]. 


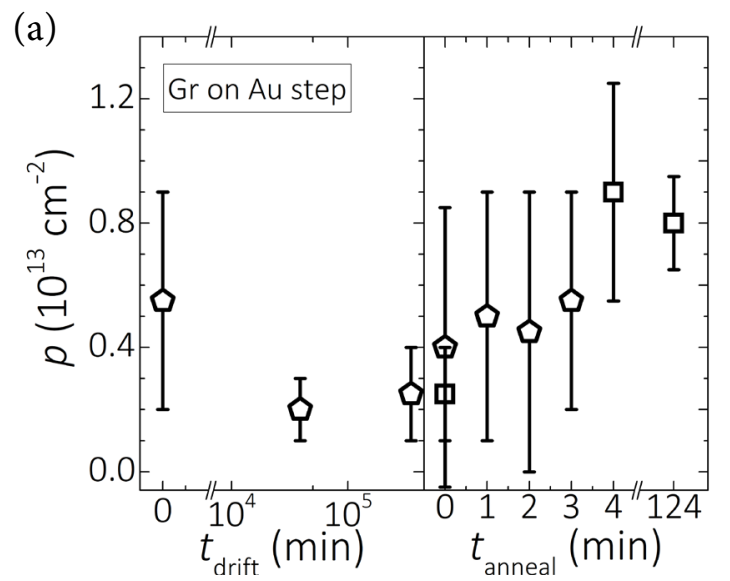

(b)

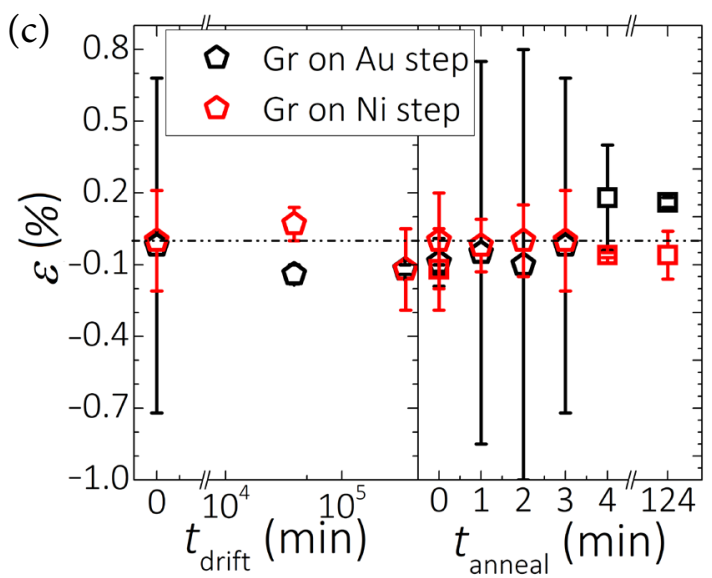

Fig. 5. Dependence of doping (a, b) and strain (c) on the drift $t_{\text {drift }}$ and annealing $t_{\text {anneal }}$ time of graphene on the edge zone of contact.

to its initial magnitudes that was characteristic before the resistance drift of both the Au and Ni CTLM samples. Figure 5(c) shows the dependence of strain in the drift and the annealing time in the graphene in the edge zone of the contact. The strain of graphene in the edge zones of contacts changed approximately from -0.1 to $0.1 \%$ over the drift period and from

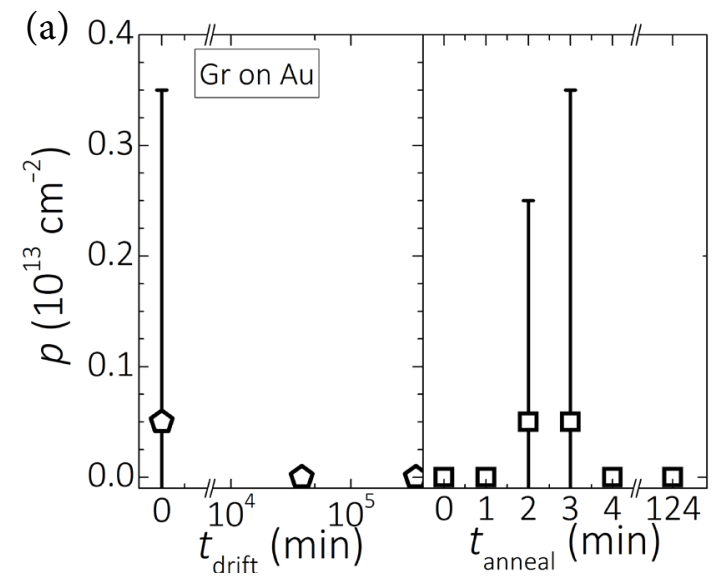

-0.1 to $0.2 \%$ during the annealing. Hence, variations in the strain were minor in the graphene in the edge zones of contacts over the long-time tests.

The dependence of doping over the entire drift and annealing tests was obtained for the graphene on the flat metal surfaces. These results are shown in Fig. 6(a) for the Au samples and 6(b) for the Ni

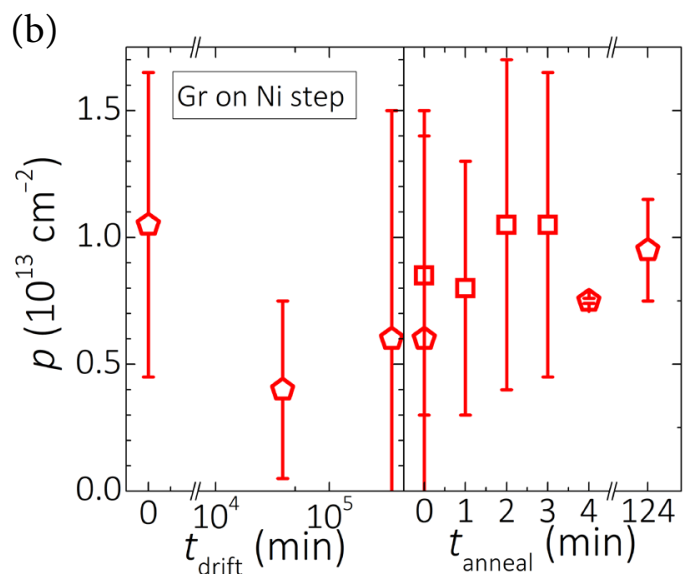

Fig. 6. Dependence of doping on the drift $t_{\text {drift }}$ and annealing $t_{\text {anneal }}$ time of graphene on (a) Au and (b) Ni metal films. 
samples. Different shapes of symbols represented the results that were obtained on the individual CTLM array on similar samples. This experiment revealed a low charge density in the graphene on the $\mathrm{Au}$ contact. The charge impurity concentration decreased from $p=0.05 \times 10^{13} \mathrm{~cm}^{-2}$ to $p \sim 0$ over the resistance drift. A low concentration of carriers in the graphene can be attributed to the Fermi level that is situated in the Dirac point in the graphene. The charge density was returned to its initial magnitudes in 2 min of the annealing. A slight increase of the charge density was introduced after the annealing time reached 2 and $3 \mathrm{~min}$. These results confirmed a very low charge impurity doping for the graphene that was placed on the $\mathrm{Au}$ surface. The decrease in charge density was detected being from $0.4 \times 10^{13}$ to $0.3 \times 10^{13} \mathrm{~cm}^{-2}$ for the graphene on the Ni electrodes after the drift. However, the doping increased from $0.3 \times 10^{13}$ to $0.47 \times 10^{13} \mathrm{~cm}^{-2}$ after the annealing. The values of charge doping in the graphene on the flat Ni surfaces was attributed to the $p$-type doping. The reduction of $p$-type doping over the long drift was also observed in Ref. [17]. Furthermore, the authors perceived that $p$-type doping increased over the annealing time [17]. This dependence was observed using different gas in the annealing chamber. Moreover, the charge density for the samples with a high binding metal Ni contact was higher than that for the samples with low binding metal Au contacts.

The dependence of strain over the drift and annealing in the graphene on the $\mathrm{Au}$ and $\mathrm{Ni}$ elec-

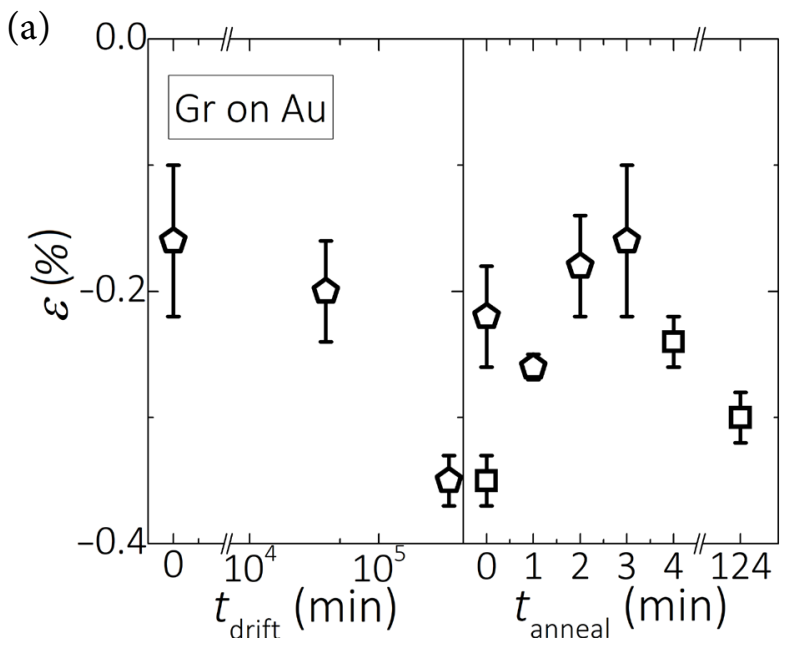

trodes is presented in Fig. $7(\mathrm{a}, \mathrm{b})$. The increase in the compressive strain was obtained for the $\mathrm{Au}$ samples during the resistance drift. The compressive strain $\varepsilon=-0.16 \%$ was observed before the drift. However, the compressive strain was increased to $-0.35 \%$ after the resistance drift. The increase of compressive strain was also noticed in the graphene sheet in Ref. [17]. The strain was restored to its initial magnitudes after the annealing period. The compressive strain decreased to $-0.16 \%$ for the annealing duration about $3 \mathrm{~min}$. The compressive strain increased to $-0.3 \%$ when the annealing was over $3 \mathrm{~min}$. Considering the fact that the charge density was very low in the graphene on the $\mathrm{Au}$ surfaces over the long-term tests, we supposed that changes in the strain might be more important in the graphene on the Au film. A decrease in the tensile strain was observed in the graphene on the $\mathrm{Ni}$ electrodes over the resistance drift as it is shown in Fig. 7(b). The strain decreased from 0.6 to $0.1 \%$ after the drift. The annealing induced the increase of tensile strain from 0.1 to $0.15 \%$. However, the rise was observed in the $\varepsilon(\%)$ after 3 min of the annealing. The increase of compressive strain in the graphene on the metal surface over the resistance drift could be associated with the diffusion of atmospheric water through the graphene sheet. The annealing may cause the removal of water, therefore the decrease of compressive strain was observed in the graphene on the Au surface in our experiment. Van-der-Waals force is a crucial factor for the chemical reactivity of graphene [18]. Therefore, adsorption and redox to the graphene layer are mainly responsible for

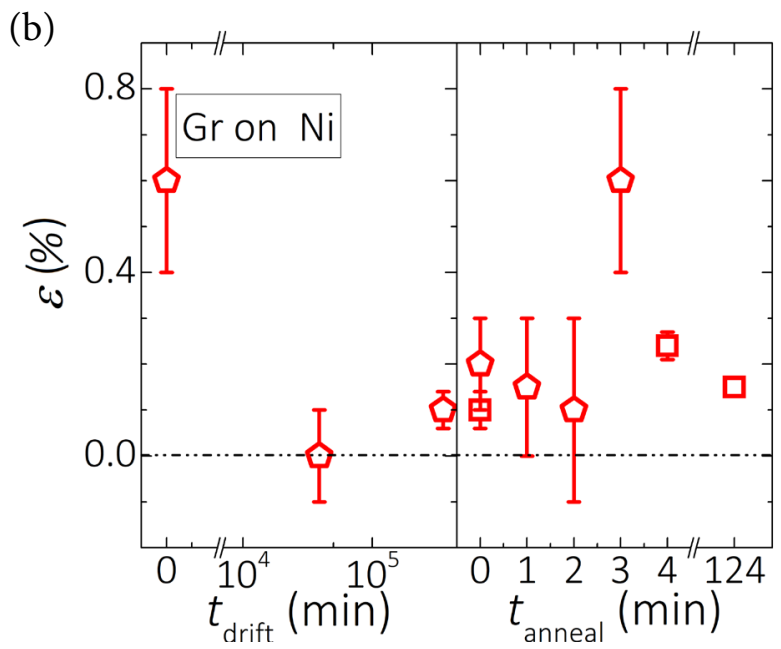

Fig. 7. Dependence of strain on the drift $t_{\text {drift }}$ and annealing $t_{\text {anneal }}$ time of graphene on (a) Au and (b) Ni metal films. 
the variation of charge density [19, 20]. These processes could be reasonable for the variation of doping and the strain in the graphene monolayer during the long-term stability tests.

Figure 8 shows the changes of doping (a) and strain (b) in the graphene sheet on the flat surfaces of $\mathrm{SiO}_{2}$ substrate for the $\mathrm{Au}$ and $\mathrm{Ni}$ samples. The charge doping of graphene on the $\mathrm{SiO}_{2}$ substrate was obtained being from $0.4 \times 10^{13}$ to $1.55 \times 10^{13} \mathrm{~cm}^{-2}$ over the drift test period. The results are demonstrated in Fig. 8(a). The charge density changed between 0.6 and $1.5\left(\times 10^{13} \mathrm{~cm}^{-2}\right)$ during the annealing. The strain of graphene on the $\mathrm{SiO}_{2}$ substrate changed from -0.16 to $0.04 \%$ over the drift period. The $\varepsilon(\%)$ varied in the -0.16 to $0.02 \%$ range over the annealing period. The relative variation of carrier concentrations on the resistance drift and annealing was lower compared to that in the graphene in the edge zones of contacts. In addition, the changes of $\varepsilon(\%)$ in the graphene on $\mathrm{SiO}_{2}$ were less detectable than those on
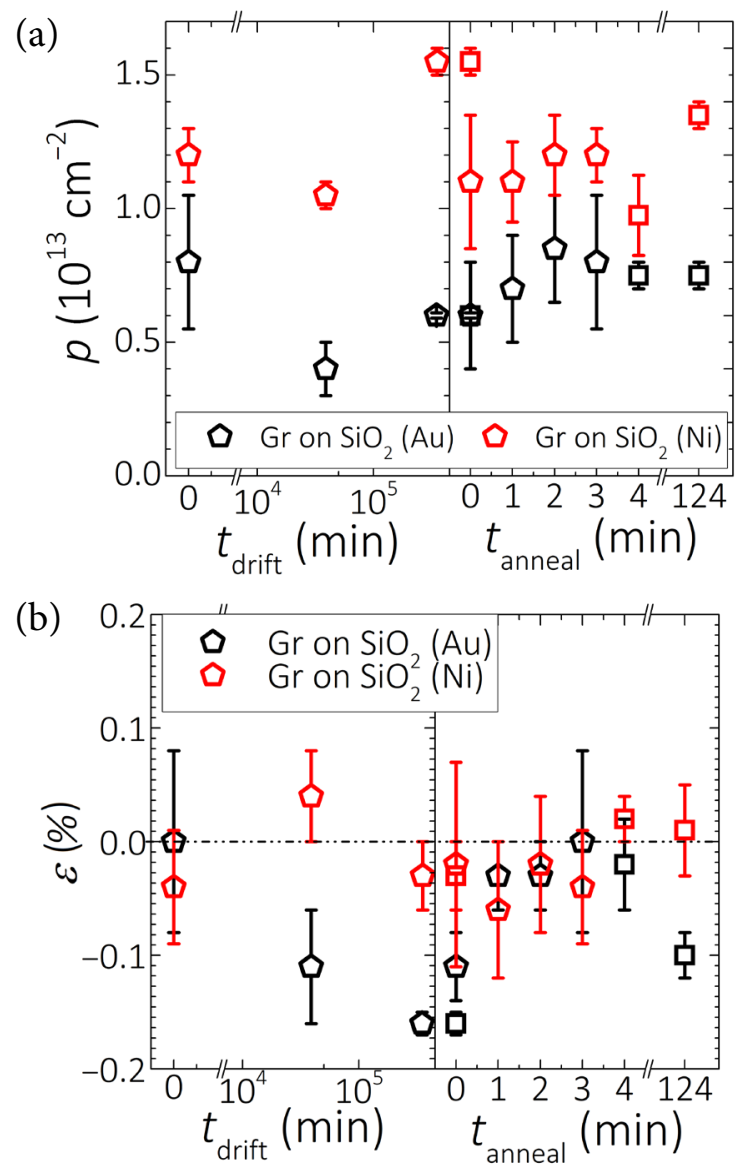

Fig. 8. Dependence of $p$-type doping (a) and strain (b) on the $t_{\text {drif }}$ and $t_{\text {anneal }}$ for the graphene on the $\mathrm{SiO}_{2}$ substrate. the flat surfaces of metal during the resistance drift and annealing.

\section{KPFM measurements}

The CTLM samples were characterized by SPM aiming to build up a map of the work function of the graphene on the CTLM samples. Typical SPM images of the morphology and the contact potential difference (CPD) are presented in Fig. 9 .

The work function is related to the Fermi level in the graphene sheet. The work function $W_{\mathrm{Gr}}$ of undoped CVD graphene was known being equal
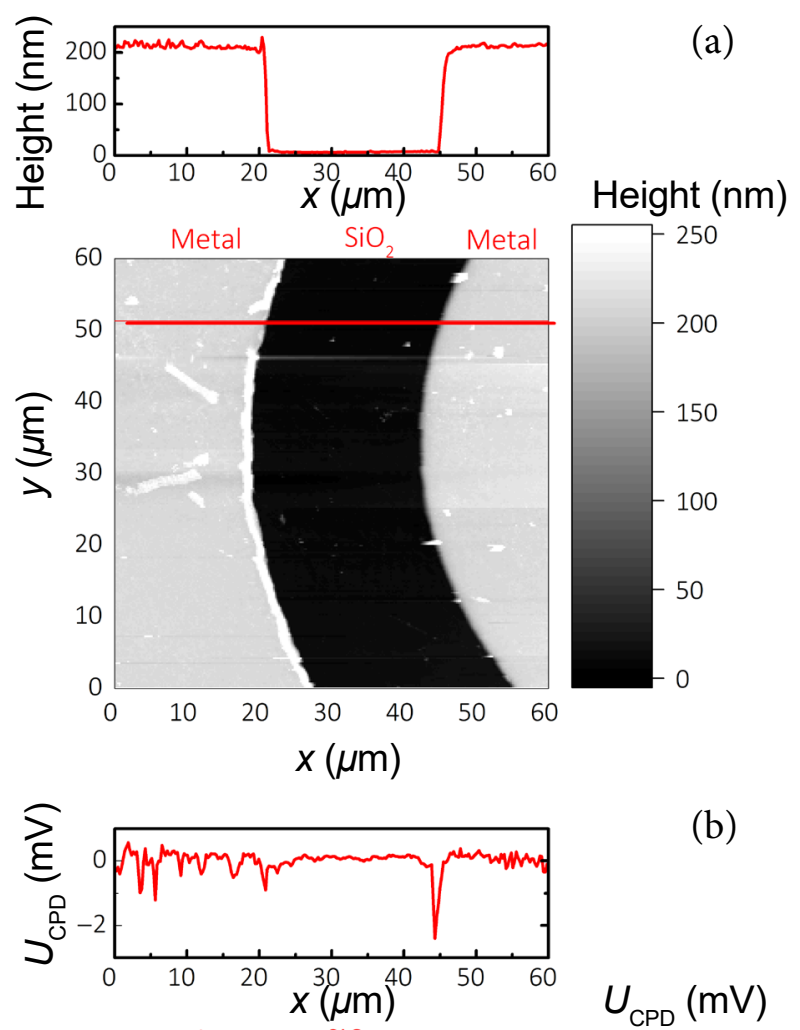

(b)

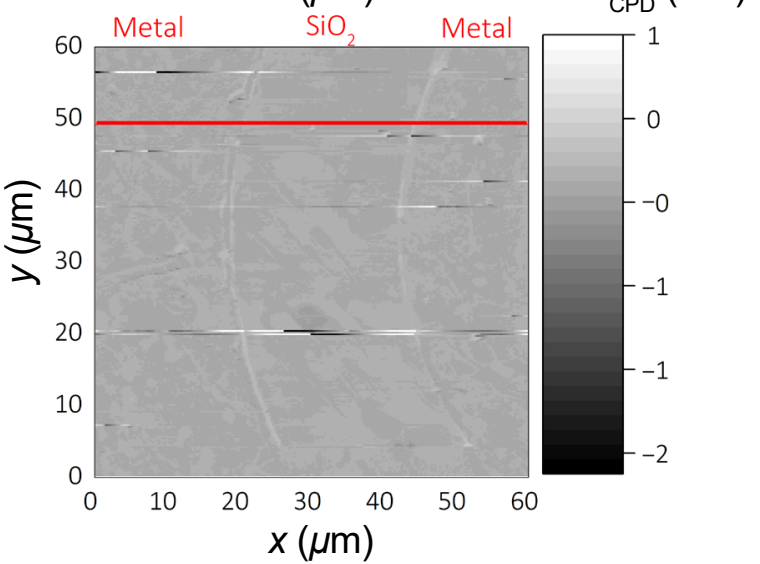

Fig. 9. SPM images of the surfaces in the CTLM samples. The images were obtained in the topography (a) and KPFM (b) modes. 
to $4.53 \mathrm{eV}$ [21]. The p-type of the doping of graphene was accepted correspondent to the work function $W_{\mathrm{Gr}}$ higher than $4.53 \mathrm{eV}$. The $n$-type of the doping in graphene was related to the work function $W_{\mathrm{Gr}}<4.53 \mathrm{eV}$. In our work, SPM measurements were made after the resistance drift and annealing. The dependence of the work function on the annealing time is shown in Fig. 10. $W_{\mathrm{Gr}}$ of the graphene was obtained on the metal electrodes, the edge zone of the contact and on the $\mathrm{SiO}_{2}$ substrate. Measurements of $W_{\mathrm{Gr}}$ were performed for the both $\mathrm{Au}$ and Ni samples.

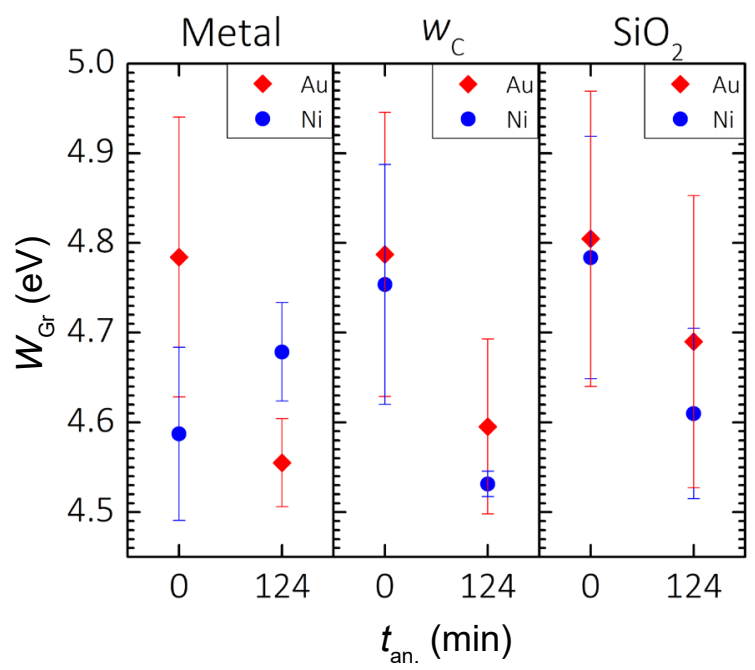

Fig. 10. Changes in the work function $W_{\mathrm{Gr}}$ before and after annealing of graphene. $W_{\mathrm{Gr}}$ was obtained at different zones of the sample, namely on metal, on the contact edge zone and on $\mathrm{SiO}_{2}$.

The work function for the graphene on the $\mathrm{Au}$ surfaces was equal to $4.78 \mathrm{eV}$ after the resistance drift. This confirms the $p$-type doping of the graphene on the Au electrodes. However, the work function decreased after the annealing and it was equal to $4.56 \mathrm{eV}$. The work function of the graphene on the Ni flat surfaces was equal to $4.59 \mathrm{eV}$ after the drift. $W_{\mathrm{Gr}}$ of the graphene on the Ni electrodes slightly increased after the annealing and was equal to $4.68 \mathrm{eV}$. The $p$-type doping was observed in the graphene on the Ni film after the resistance drift and annealing experiment.

The work function of the graphene in the edge zones of contacts for the Au samples changed from 4.79 to $4.60 \mathrm{eV}$ on annealing. The work function of the graphene in the edge zones of contacts for the Ni samples decreased from 4.75 to $4.53 \mathrm{eV}$.
The dependence of work function on the annealing of graphene on the $\mathrm{SiO}_{2}$ substrate is shown in Fig. 10. The reduction of work function of the graphene on $\mathrm{SiO}_{2}$ was observed for both the $\mathrm{Au}$ and $\mathrm{Ni}$ CTLM samples.

\section{Conclusions}

We have investigated the drift of the electrical characteristics, namely the total resistance $R_{\mathrm{d}}$, contact resistance $R_{\mathrm{C}}$ and sheet resistance $R_{\mathrm{Sh}}$ for the CVD graphene based $\mathrm{Au}$ and Ni contacts. The decrease of the total resistance $R_{\mathrm{d}}$ was observed for both the $\mathrm{Au}$ and Ni CTLM samples during the drift. Furthermore, the reduction of contact resistance and sheet resistance was perceived on the drift of CVD graphene based resistors. The change of resistance could be attributed to the variations of charge doping and the change of deformation in the graphene on metal contact. The Raman analysis revealed the decrease in $p$-type doping in the graphene in the edge zones of contacts for the $\mathrm{Au}$ and $\mathrm{Ni}$ samples over the resistance drift. A notable decrease in the $p$-type doping was observed in the graphene on the flat $\mathrm{Au}$ and $\mathrm{Ni}$ surfaces. The strain mechanism was dominant in the graphene on the Au surfaces over the long stability tests because only a low charge density was obtained in the graphene on the Au films. The resistance drift was related to the increase in compressive strain in the graphene on the Au contacts, whereas tensile strain was obtained for the Ni samples. The electrical characteristics were restored to the initial magnitudes by annealing at $573 \mathrm{~K}$. At this step of the long-term tests, the increase in the doping was observed in the graphene in the edge zones of contacts for the both the $\mathrm{Au}$ and $\mathrm{Ni}$ samples. Moreover, the annealing induced the increase in $p$ type doping $\left(<10^{13} \mathrm{~cm}^{-2}\right)$ in the graphene on the flat surfaces of $\mathrm{Ni}$. The low $p$-type doping was produced in the graphene on the Au electrodes by annealing. The decrease in compressive strain was confirmed in the graphene on the flat Au surfaces in the annealing tests. However, the increase of tensile strain was observed in the graphene sheet on the Ni films. The SPM experiments revealed the change of work function in the annealing experiments. The largest change of $W_{\mathrm{Gr}}$ was observed in the graphene on the flat surfaces of Au films and in the graphene at the edge zones of contacts for the $\mathrm{Ni}$ samples. The changes in work function during the annealing 
proved that the type of doping in the graphene in the $\mathrm{Au}$ and Ni samples remained the same as it was before the annealing procedures. This study demonstrated that the edge zones of the CVD graphene based metal contacts were the most sensitive part to long-term stability.

\section{References}

[1] X. Gan, R.-J. Shiue, Y. Gao, I. Meric, T.F. Heinz, K. Shepard, J. Hone, S. Assefa, and D. Englund, Chip-integrated ultrafast graphene photodetector with high responsivity, Nat. Photonics 7, 883-887 (2013), https://doi.org/10.1038/nphoton.2013.253

[2] A.D. Smith, S. Vaziri, S. Rodriguez, M. Östling, and M.C. Lemme, Large scale integration of graphene transistors for potential applications in the back end of the line, Solid State Electron. 108, 61-66 (2015), https://doi.org/10.1016/j. sse.2014.12.014

[3] M. Liu, X. Yin, E. Ulin-Avila, B. Geng, T. Zentgraf, L. Ju, F. Wang, and X. Zhang, A graphene-based broadband optical modulator, Nature 474(7349), 64-67 (2011), https://doi.org/10.1038/nature10067

[4] A.D. Smith, F. Niklaus, A. Paussa, S. Vaziri, A.C. Fischer, M. Sterner, F. Forsberg, A. Delin, D. Esseni, P. Palestri, M. Östling, and M.C. Lemme, Electromechanical piezoresistive sensing in suspended graphene membranes, Nano Lett. 13(7), 3237-3242 (2013), https://doi.org/10.1021

[5] A.D. Smith, K. Elgammal, F. Niklaus, A. Delin, A.C. Fischer, S. Vaziri, F. Forsberg, M. Råsander, H. Hugosson, L. Bergqvist, S. Schröder, S. Kataria, M. Östling, and S. Schröder, Resistive graphene humidity sensors with rapid and direct electrical readout, Nanoscale 7(45), 19099-19109 (2015), https://doi.org/10.1039/C5NR06038A

[6] A. Gahoi, S. Wagner, A. Bablich, S. Kataria, V. Passi, and M.C. Lemme, Contact resistance study of various metal electrodes with CVD graphene, Solid State Electron. 125, 234-239 (2016), https://doi.org/10.1016/j.sse.2016.07.008

[7] J.W. Suk, W.H. Lee, J. Lee, H. Chou, R.D. Piner, Y. Hao, D. Akinwande, and R.S. Ruoff, Enhancement of the electrical properties of graphene grown by chemical vapor deposition via controlling the effects of polymer residue, Nano Lett. 13(4), 1462-1467 (2013), https://doi.org/10.1021/ nl304420b

[8] A. Avsar, I.J. Vera-Marun, J.Y. Tan, K. Watanabe, T. Taniguchi, A.H. Castro Neto, and B. Ozyilmaz, Air-stable transport in graphene-contacted, fully encapsulated ultrathin black phosphorus-based field-effect transistors, ACS Nano 9(4), 4138-4145 (2015), https://doi.org/10.1021/acsnano.5b00289

[9] U. Lee, Y. Han, S. Lee, J.S. Kim, Y.H. Lee, U.J. Kim, and $\mathrm{H}$. Son, Time evolutional studies on strain and doping of graphene grown on a copper substrate using Raman spectroscopy, ACS Nano 14(1), 919-926 (2020), https://doi.org/10.1021 acsnano.9b08205

[10]S. Ryu, L. Liu, S. Berciaud, Y.J. Yu, H. Liu, P. Kim, G.W. Flynn, and E.B. Louis, Atmospheric oxygen binding and hole doping in deformed graphene on a $\mathrm{SiO}_{2}$ substrate, Nano Lett. 10(12), 4944-4951 (2010), https://doi.org/10.1021/nl1029607

[11]A. Piazza, F. Giannazzo, G. Buscarino, G. Fisichella, A. La Magna, F. Roccaforte, M. Cannas, F.M. Gelardi, B. Pignataro, M. Scopelliti, and S. Agnello, Substrate and atmosphere influence on oxygen p-doped graphene, Carbon 107, 696-704 (2016), https://doi.org/10.1016/j.carbon.2016.06.077

[12]A. Quellmalz, A.D. Smith, K. Elgamma, X. Fan, A. Delin, M. Östling. M. Lemme, K.B. Gylfason, and F. Niklaus, Influence of humidity on contact resistance in graphene devices, ACS Appl. Mater. Interfaces 10(48), 41738-41746 (2018), https:// doi.org/10.1021/acsami.8b10033

[13]J. Kang, D. Shin, S. Bae, and B.H. Hong, Graphene transfer: key for applications, Nanoscale 4(18), 5527-5537 (2012), https://doi.org/10.1039 C2NR31317K

[14]A. Sakavičius, G. Astromskas, A. Lukša, V. Bukauskas, V. Nargelienè, I. Matulaitienè, and A. Šetkus, Annealing time effect on metal graphene contact properties, ECS J. Solid State Sci. Technol. 7(5), M77-M81 (2018), https://doi. org/10.1149/2.0201805jss

[15] A. Sakavičius, G. Astromskas, V. Bukauskas, M. Kamarauskas, A. Lukša, V. Nargelienė, G. Niaura, 
I. Ignatjev, M. Treideris, and A. Šetkus, Long distance distortions in the graphene near the edge of planar metal contacts, Thin Solid Films 698, 137850 (2020), https://doi.org/10.1016/j. tsf.2020.137850

[16]J.E. Lee, G. Ahn, J. Shim, Y.S. Lee, and S. Ryu, Optical separation of mechanical strain from charge doping in graphene, Nat. Commun. 3, 1024 (2012), https://doi.org/10.1038/ncomms2022

[17]A. Armano, C. Buscarino, M. Cannas, F.M. Gelardi, F. Giannazzo, E. Schilirò, and S. Agnello, Monolayer graphene doping and strain dynamics induced by thermal treatments in controlled atmosphere, Carbon 127, 270-279 (2018), https://doi.org/10.1016/j.carbon.2017.11.008

[18]J.H. Lee, A. Avsar, J. Jung, J.Y. Tan, K. Watanabe, T. Taniguchi, S. Natarajan, G. Eda, S. Adam, A.H. Castro Neto, and B. Özyilmaz, Van der Waals force: a dominant factor for reactivity of graphene, Nano Lett. 15(1), 319-325 (2015), https://doi.org/10.1021/nl5036012
[19]S. Schumacher, T.O. Wehling, P. Lazic, S. Runte, D.F. Förster, C. Busse, M. Petrović, M. Kralj, S. Blügel, N. Atodiresei, V. Caciuc, and T. Michely, The backside of graphene: manipulating adsorption by intercalation, Nano Lett. 13(11), 50135019 (2013), https://doi.org/10.1021/nl402797j

[20]P.L. Levesque, S.S. Sabri, C.M. Aguirre, J. Guillemette, M. Siaj, P. Desjardins, T. Szkopek, and R. Martel, Probing charge transfer at surfaces using graphene transistors, Nano Lett. 11(1), 132137 (2011), https://doi.org/10.1021/nl103015w

[21]M.M. Giangregorio, W. Jiao, G.V. Bianco, P. Capezzuto, A.S. Brown, G. Bruno, and M. Losurdo, Insights into the effects of metal nanostructuring and oxidation on the work function and charge transfer of metal/graphene hybrids, Nanoscale 7(30), 12868-12877 (2015), https://doi.org/10.1039/c5nr02610e

\title{
GRAFENO IR METALO KONTAKTUU ELEKTRINIŲ CHARAKTERISTIKŲ KITIMAS DÉL ILGALAIKIO DREIFO
}

\author{
A. Sakavičius, V. Agafonov, V. Bukauskas, T. Daugalas, M. Kamarauskas, A. Lukša, V. Nargelienė, \\ G. Niaura, M. Treideris, A. Šetkus
}

Fiziniu ir technologijos mokslu centras, Vilnius, Lietuva

\begin{abstract}
Santrauka
Darbe pristatomas tyrimas, kuriame buvo analizuotos CVD (cheminio garų nusodinimo) grafeno pagrindu pagamintu $\mathrm{Au}$ ir Ni CTLM (apskritiminès perdavimo linijos metodo) varžinių darinių elektrinių charakteristikų ilgalaikio stabilumo priežastys. Kontaktų iškaitinimas buvo naudojamas elektrines varžas atstatant i pradines vertes, būdingas tik ką pagamintiems grafeno bandiniams. Iškaitinimas buvo atliekamas Ar sraute, $573 \mathrm{~K}$ temperatūroje. Dèl parametrų kitimo bėgant laikui pasikeitusi grafeno bandinių elektrinè varža, kontaktinès ir sluoksnio varžos buvo atstatytos i pradines vertes.

Ramano spektroskopija buvo tirtas grafeno, esančio ant bandinių paviršiaus, legiravimo ir ịtempimų kitimas begant laikui ir atstatymo metu. Analizuotos trys grafeno CTLM bandinių sritys: grafenas, esantis ant metalinių kontaktur, grafenas, esantis ant kontaktinio laiptelio srities, ir grafenas, esantis ant $\mathrm{SiO}_{2}$ padèklo. Nustatyta, kad
\end{abstract}

dèl bandinių kitimo bègant laikui ir atstatymo didžiausi legiravimo kitimai ịvyko grafeno sluoksnyje, esančiame ant kontaktinio laiptelio srities, o didžiausi itempimu pokyčiai - grafeno sluoksnyje, esančiame ant metalinių kontaktur.

Kelvino jègos spektroskopijos mikroskopija išmatuotos grafeno išlaisvinimo darbo vertès prieš CTLM bandinių iškaitinimą ir po. Nustatyta, kad išlaisvinimo darbo vertè sumažèjo grafeno sluoksnyje, esančiame ant $\mathrm{Au}$ kontaktų; po iškaitinimo ji padidèjo grafeno sluoksnyje, esančiame ant Ni kontaktų, ir $W_{\mathrm{Gr}}$ sumažèjo grafeno sluoksnyje, esančiame ant kontaktinio laiptelio srities bei $\mathrm{SiO}_{2}$ padèklo. Išlaisvinimo darbo pokytis grafeno sluoksnyje, esančiame ant metalinių kontaktų, buvo didžiausias Au CTLM bandiniams, o $W_{\text {Gr }}$ pokytis grafeno sluoksnyje, esančiame ant kontaktinio laiptelio srities, - Ni CTLM bandiniams. 